\title{
Report of the Annual Meeting
}

Rapports annuels de la Société historique du Canada

\section{The Place of History in Canadian Education}

\section{Stephen Leacock}

Volume 4, numéro 1, 1925

URI : https://id.erudit.org/iderudit/300526ar

DOI : https://doi.org/10.7202/300526ar

Aller au sommaire du numéro

Éditeur(s)

The Canadian Historical Association/La Société historique du Canada

ISSN

0317-0594 (imprimé)

1712-9095 (numérique)

Découvrir la revue

Citer cet article

Leacock, S. (1925). The Place of History in Canadian Education. Report of the

Annual Meeting / Rapports annuels de la Société historique du Canada, 4(1),

33-34. https://doi.org/10.7202/300526ar 


\title{
THE PLACE OF HISTORY IN CANADIAN EDUCATION
}

\author{
By Stephen Leacock
}

A thing to which this association ought specially to devote its attention, is the encouragement of what one may call local history. In Canada we have a peculiar country. To the geologist it is the oldest in the world. To the historian a large part of it at least is the very newest. It is a country in which we can actually see at work the process of planting political and social institutions in the soil.

In ever so many districts of this country, especially in English-speaking Canada, it is still possible to trace out the story of the settlement of the land from the first corner onward; it is still possible, if we would take the time to record it, to mark the spot where stood the first house, to indicate among the motor roads of today the path of the first trail that wandered among the pines.

Yet how soon does this opportunity vanish! How soon this information is obliterated with the lapse of time. With the passage of each generation of the older people how much of memory is lost.

I can illustrate this best from the experience of my own childhood. My carliest years in Canada-from the age of six to twelve-were spent in the township of Georgina in the northeast corner of the county of York in Ontario. I had the honour to attend one of those "little red schoolhouses," that are passing into a legend-a little red-brown building with the words School Section No. 3 painted on it. At that time (in 1876) that part of the county was not in point a settlement of more than half a century old. The original settlers had come in, I presume, at some time after Yonge street was opened in 1795, but I doubt whether any of them had gone inland from the shores of lake Simcoe till some years after that. When $I$ was a child it would have still been possible to trace out the history of every house and household. The rebellion of 1837 was an event then thirty-nine years old, and several of the "rebels" were still there in the settlement. I can remember one or two of them. What an interesting story one could have taken down from the lips of any of them, or from the lips of any of the early settlers who first came in through the bush, their possessions slung over the back of a horse, traversing a trackless country under the silence of the great pines. When I was a boy I never thought of such things. History meant to me the story of Greece or Rome, of Achilles in his tall helmet, or at best of Nelson sending up the string of coloured signal flags on the bright autumn day of Trafalgar. I never realized that there was history too, close at hand, beside my very own home. I did not realize that the old grave that stood among the brambles at the foot of our farm was history. We passed it as we went by at dusk towards the cow pasture in the bush with quaking hearts; in the broad sunlight of day with bold defiance. But that the grave and its forgotten tenant were a piece of history we never guessed; it never occurred to us that it recalled a time in the days of early settlement when there was no consecrated grave yard, when each and every one must bury his own dead, $17738-3$ 
and that the grass grown spot with a rude cedar fence about it that we passed with a shudder or a laugh had been for someone in those days a place of bitter sorrow and unending memory.

Fifty years have passed since the time of which I speak, and my point of view has changed. I value none the less the great historical epics of a Macauley or a Gibbon. But I find myself drawn more and more to the charm and meaning of the history of little places. Who lived here first? Who first set the stones that lay bencath the simple frame of that log-house? How did life feel for these first-comers? Such queries and such reflections may arise in any lost corner of our countryside, and may well fill the reflecting mind with wonder and interest. For after all, the life of the individual has in its silent passage to the end the same infinite mystery and the same unfathomed meaning as the life of a nation.

In the half century that has passed since I was a child, no doubt a great part of the local history of which I speak has been lost under the successive changes of advancing settlement. The great swamp is drained and lies in white billows of buckwheat; the logging track is now a motor road, and there is afternoon tea in a sort of wayside inn on the spot where grandfather Anderson once shot the deer from the stoop of his log hut.

Such changes have to come. -But the pity is that the record should be lost. It need not be so. It ought to be the task of us in this society to animate our people, and above all the children of our schools with the idea of recording and perpetuating for all time, the simple but noble annals of our early settlement. 